\title{
KUALITAS KIMIA BISKUIT RANSUM KOMPLIT MENGGUNAKAN EMPULUR SAGU DAN DEDAK PADI SEBAGAI BAHAN PEREKAT
}

\author{
Christian Willem Patty, Lily Joris, dan Rajab \\ Jurusan Peternakan Fakultas Pertanian Universitas Pattimura, Ambon-Maluku \\ e-mail : chpatty1161@gmail.com
}

\begin{abstract}
ABSTRAK
Penelitian ini bertujuan untuk mengetahui kualitas kimia biskuit ransum komplit dengan penggunaan empulur sagu dan dedak padi sebagai pakan ternak. Bahan yang digunakan adalah empulur sagu, rumput gajah, daun lamtoro, dedak dan air. Penelitian menggunakan rancangan acak lengkap (RAL) dengan 5 perlakuan yaitu P1 (25\% empulur sagu $+5 \%$ dedak padi), P2 (20\% empulur sagu $+10 \%$ dedak padi), P3 ( $15 \%$ empulur sagu $+15 \%$ dedak padi), $\mathrm{P}_{4}$ (10\% empulur sagu $+20 \%$ dedak padi), dan $\mathrm{P}_{5}$ ( $5 \%$ empulur sagu $+25 \%$ dedak padi). Setiap perlakuan terdiri dari 5 ulangan. Hasil penelitian menunjukkan bahwa penggunaan empulur sagu sampai 25\% dan dedak padi 5\% (perlakuan P1) mempunyai kadar air tertinggi 7,14\%, protein kasar terrendah 10,19\%, lemak kasar terrendah 1,72\%, dan kadar BETN tertinggi 57,53\%. Sebaliknya penggunaan dedak padi yang lebih tinggi sampai $25 \%$ dan empulur sagu $5 \%$ (perlakuan $\mathrm{P}_{5}$ ) mempunyai kadar air terrendah 6,09\%, protein kasar tertinggi 11,99\%, dan lemak kasar tertinggi 3,35\%. Dapat disimpulkan bahwa kualitas kimia biskuit pada perlakuan $\mathrm{P}_{5}$ lebih baik, karena kadar proteinnya lebih tinggi, tetapi kadar air dan kadar serat kasarnya lebih rendah.
\end{abstract}

Kata kunci: empulur sagu, dedak padi, kualitas kimia, biskuit ransum komplit

\section{CHEMICAL QUALITY OF COMPLETE RATION BISCUIT USING SAGO PITH AND RICE BRAN}

\begin{abstract}
The objective of this study was to determine the chemical quality of biscuit using sago pith and rice bran as feed stuff. Sago pith, chopped elephant grass, rice brand, lamtoro leaves and water were used. The method conducted by using complete randomized design with 5 treatments were $\mathrm{P}_{1}$ ( $25 \%$ sago pith $+5 \%$ rice bran), $\mathrm{P} 2$ ( $20 \%$ sago pith $+10 \%$ rice bran), $\mathrm{P}_{3}$ ( $15 \%$ sago pith $+15 \%$ rice bran), $\mathrm{P} 4$ ( $10 \%$ sago pith $+20 \%$ rice bran), and $\mathrm{P}_{5}$ ( $5 \%$ sago pith $+25 \%$ rice bran). Each treatment consisted of 5 replications. The results showed that the use of sago pith up to $25 \%$ and $5 \%$ rice bran (treatment $\mathrm{P} 1$ ) had the highest water content was $7.14 \%$, the lowest crude protein was $10.19 \%$, the lowest crude fat was $1.72 \%$, and the highest BETN content was $57.53 \%$. In contrast, the use of rice bran which was higher up to $25 \%$ and $5 \%$ sago pith (treatment $\mathrm{P}_{5}$ ) had the lowest water content of $6.09 \%$, the highest crude protein was $11.99 \%$, and the highest crude fat was $3.35 \%$. It can be concluded that chemical quality of $\mathrm{P}_{5}$ is higher than the others because of high protein and low water and lipid contents.
\end{abstract}

Key words: sago pith, rice bran, chemical quality, complete ration biscuit

\section{PENDAHULUAN}

Ketersediaan pakan hijauan, utamanya hijauan segar terkadang menjadi kendala dalam pemeliharaan ternak ruminansia (Syam et al., 2016). Ketersediaan pakan menjadi kendala utama khususnya di negara berkembang karena suplai hijauan pakan ternak (HPT) baik dari segi kualitas maupun kuantitas selalu mengalami kelangkaan dan berfluktuasi sepanjang tahun. Terbatasnya ketersediaan hijauan menyebabkan lebih banyak pemanfaatan pakan berserat yang berasal dari limbah tanaman pangan.
Limbah berserat tersebut merupakan sumber pakan yang penting bagi ternak ruminansia hingga saat ini (Retnani et al., 2011; Ajayi et al., 2005).

Salah satu teknologi pengolahan pakan yang dapat dilakukan untuk mengatasi kelangkaan hijauan makanan ternak adalah melalui pembuatan biskuit ransum komplit, yang merupakan suatu bentuk pakan yang memiliki kandungan nutrisi lengkap, dibuat dengan teknologi sederhana, mempunyai bentuk fisik kompak dan ringkas sehingga memudahkan dalam penanganan dan pemberian pada ternak (Trisyulianti et al., 2003). Dalam pembuatan biskuit 
komplit, dibutuhkan bahan perekat untuk mengikat komponen-komponen bahan pakan agar mempunyai struktur yang kompak sehingga tidak mudah hancur dan mudah dibentuk pada proses pembuatannya, serta mudah dalam pengemasan, pengangkutan dan penyimpanan (Syahri et al., 2018; Wati et al., 2020).

Bahan perekat ada dua jenis yaitu sintesis dan alami. Bahan perekat sintetis yang biasa digunakan dalam pembuatan pakan ternak di industri makanan ternak antara lain carboksil metil cellulosa (CMC) yang relatif mahal. Perlu dicari bahan perekat alternatif yang lebih murah, dijamin ketersediaannya, aman, serta mempunyai daya rekat yang tinggi (Sandi et al., 2015). Bahan perekat alami mensyaratkan bahan mengandung pati seperti kanji, molases (Krisnan dan Ginting 2009), tepung tapioka (Syamsu, 2007).

Salah satu bahan potensial sebagai perekat adalah empulur dari sagu (Metroxylon sagu Rottb). Empulur sagu merupakan bagian batang sagu yang mengandung protein kasar 18,86\%, lemak kasar o,09\% dan serta kasar 8,82\% (Jaelani et al., 2013). Penggunaan empelur sagu sebagai bahan perekat dalam pembuatan biscuit pakan ternak berfungsi mengikat kompenen-komponen pakan sehingga strukturnya tetap kompak karena empelur sagu mengandung $83,50 \%$ pati. Pati terdiri dari dua fraksi yang dapat dipisahkan oleh air panas yaitu amilosa dan amilopektin. Semakin besar kandungan pati akan semakin basah, lengket dan cendrung sedikit mengikat air (Fredriksz dan Joris, 2020).

Selain empulur sagu, dedak padi juga dapat digunakan sebagai bahan perekat dalam pembuatan biskuit ransum komplit karena mengandung amilosa (Rahmana et al., 2016). Menurut Winarno (1997), amilosa merupakan fraksi pati yang larut dalam air panas dan dapat terbebaskan (leaching) keluar granula ketika tergelatinisasi. Dengan demikian, saat tergelatinisasi fraksi amilosa yang dibebaskan keluar granula lebih banyak sehingga tingkat kelarutannya lebih tinggi. Bahan-bahan perekat ini dapat diuji penggunaannya dalam pembuatan biskuit pakan komplit. Selain efektivitas daya rekatnya, kandungan gizi yang terkandung di dalamnya, diharapkan dapat memperkaya biskuit pakan komplit yang dihasilkan. Penelitian ini bertujuan untuk mengetahui kualitas kimia biskuit ransum komplit yang menggunakan empulur sagu dan dedak padi sebagai bahan perekat.

\section{MATERI DAN METODE}

Bahan yang digunakan dalam pembuatan biskuit ransum komplit ini antara lain empulur sagu, dedak padi, rumput gajah (Pennisetum purpureum Schaum) dan daun lamtoro (Leucaena leucocephala). Peralatan yang digunakan antara lain timbangan digital, chopper, cetakan, oven listrik serta kompor gas.

Rumput gajah dicacah (chopping) untuk mendapatkan ukuran kira-kira 2-5 cm, selanjutnya rumput gajah dan daun lamtoro dijemur (drying) menggunakan sinar matahari selama 7 hari sampai bahan baku memiliki kadar air kurang dari $14 \%$. Masing-masing bahan (empulur sagu, dedak padi, rumput gajah, dan daun lamtoro) kemudian digiling menggunakan alat penggiling (hummer mild) hingga berukuran tepung (mash). Selanjutnya rumput gajah, daun lamtoro, empulur sagu dan dedak dicampur secara manual hingga merata dengan tambahan air dingin sebanyak $200 \mathrm{ml}$. Adonan dimasukkan dalam cetakan berbentuk bulat/lingkaran yang telah dipanaskan terlebih dahulu pada suhu $90-100^{\circ} \mathrm{C}$ di atas kompor selama 1 menit. Setelah itu, cetakan yang berisikan campuran bahan dipanaskan kembali di atas kompor selama kurang lebih 3 menit hingga berbentuk biskuit. Diangkat biskuit ransum komplit yang telah kompak atau mengikat bahan satu dengan yang lain dari alat cetakan, kemudian dimasukkan ke dalam oven dengan suhu $60^{\circ} \mathrm{C}$ untuk dikeringkan selama 24 jam.

Biskuit ransum komplit yang telah kering, digiling hingga berbentuk tepung untuk dilakukan analisis proksimat. Variabel kualitas kimia yang diuji antara lain kadar air, kadar protein kasar, kadar lemak kasar, kadar serat kasar, dan kadar BETN.

Penelitian menggunakan rancangan acak lengkap (RAL) dengan lima (5) perlakuan, dimana masingmasing perlakuan terdiri dari 5 ulangan. Adapun perlakuan yang dicobakan yaitu $\mathrm{P} 1$ (50\% rumput gajah $+20 \%$ daun lamtoro $+25 \%$ empulur sagu + $5 \%$ dedak padi); P2 (50\% rumput gajah $+20 \%$ daun lamtoro $+20 \%$ empulur sagu $+10 \%$ dedak padi); $\mathrm{P}_{3}$ (50\% rumput gajah $+20 \%$ daun lamtoro $+15 \%$ empulur sagu $+15 \%$ dedak padi); $\mathrm{P} 4$ (50\% rumput gajah $+20 \%$ daun lamtoro $+10 \%$ empulur sagu + $20 \%$ dedak padi); dan $\mathrm{P}_{5}$ (50\% rumput gajah $+20 \%$ daun lamtoro $+5 \%$ empulur sagu $+25 \%$ dedak padi). Persentase bahan-bahan tersebut berdasarkan bahan kering (BK) bahan pakan.

Data yang diperoleh dianalisis menggunakan metode analisis sidik ragam (analysis of vaviance). Bila terdapat perbedaan pengaruh perlakuan terhadap kandungan nutrisi biskuit ransum komplit maka dilanjutkan dengan uji Duncan's Multiple Range Test (DMRT).

\section{HASIL DAN PEMBAHASAN}

Penggunaan empulur sagu dan dedak padi sebagai bahan perekat terhadap kandungan nutrisi (meliputi kadar air, protein, lemak, serat kasar, dan kadar BETN) biskuit ransum komplit pada penelitian ini seperti tertera pada pada Tabel 1. 
Tabel 1. Kadar air, protein, lemak serat kasar dan BETN biskuit ransum komplit menggunakan empulur sagu sebagai perekat dan dedak padi

\begin{tabular}{|c|c|c|c|c|c|}
\hline \multirow{2}{*}{ KandunganNutrisi } & \multicolumn{5}{|c|}{ Perlakuan (\%) } \\
\hline & $\mathrm{P} 1$ & $\mathrm{P} 2$ & $\mathrm{P}_{3}$ & $\mathrm{P}_{4}$ & $\mathrm{P}_{5}$ \\
\hline Kadar Air & $7,14^{\mathrm{a}} \pm 0,55$ & $6,717^{\mathrm{ab}} \pm 0,38$ & $6,25^{\mathrm{b}} \pm 0,21$ & $6,097^{\mathrm{b}} \pm 0,51$ & $6,096^{\mathrm{b}} \pm 0,38$ \\
\hline Kadar Protein Kasar & $10,19^{b} \pm 0,63$ & $10,89^{a b} \pm 0,52$ & $11,69^{a b} \pm 1,40$ & $11,40^{a b} \pm 0,35$ & $11,99^{\mathrm{a}} \pm 0,70$ \\
\hline Kadar Lemak Kasar & $1,72^{c} \pm 0,14$ & $2,49^{b c} \pm 0,67$ & $2,89^{\mathrm{ab}} \pm 0,38$ & $2,73^{\mathrm{ab}} \pm 0,47$ & $3,35^{\mathrm{a}} \pm 0,14$ \\
\hline Kadar Serat Kasar & $20,87^{\mathrm{a}} \pm 1,14$ & $20,14^{\mathrm{a}} \pm 1,43$ & $20,73^{\mathrm{a}} \pm 1,69$ & $18,94^{\mathrm{a}} \pm 1,11$ & $18,62^{\mathrm{a}} \pm 1,12$ \\
\hline Kadar BETN & $57,53^{\mathrm{a}} \pm 0,56$ & $56,75^{\mathrm{b}} \pm 0,95$ & $54,553^{\mathrm{d}_{ \pm 1,0}}$ & $56,836^{\mathrm{b}} \pm 1,08$ & $55,582^{c} \pm 0,85$ \\
\hline
\end{tabular}

Supe rskrip berbeda pada baris yang sama menunjukkan perbedaan yang nyata $(P<0,05)$

\section{Kadar Air Biskuit Pakan Komplit}

Kadar air merupakan salah satu indikator kualitas dari suatu bahan pakan. Bahan pakan yang mengandung kadar air yang lebih tinggi umumnya akan berpengaruh terhadap kandungan bahan keringnya. Hasil analisis statistik menunjukkan bahwa penggunaan empulur sagu dan dedak sebagai bahan perekat berpengaruh sangat nyata $(\mathrm{P}<\mathrm{O}, \mathrm{O1})$ terhadap kadar air biskuit ransum komplit. Uji DMRT menunjukkan perlakuan $\mathrm{P} 1$ berbeda nyata terhadap perlakuan $\mathrm{P}_{3}, \mathrm{P}_{4}$ dan $\mathrm{P}_{5}$, namun tidak berbeda nyata terhadap perlakuan $\mathrm{P} 2$.

Hasil analisis proksimat menunjukkan persentasi kadar air biskuit ransum komplit tertinggi terdapat pada perlakuan P1 (25\% empulur sagu $+5 \%$ dedak padi), sedangkan persentasi kadar air terendah terdapat pada perlakuan $\mathrm{P}_{5}$ (5\% empulur sagu + $25 \%$ dedak padi). Tingginya kadar air biskuit ransum komplit pada perlakuan P1 dan P2 disebabkan persentasi empulur sagu yang lebih tinggi sebagai bahan perekat dan dedak padi lebih sedikit sehingga nilai pengembangan tebal biskuit cenderung berkurang. Kadar air empulur sagu berkisar 14,01 16,90\% (Purwani et al., 2006) lebih tinggi dibanding kadar air dedak padi yang berkisar 9,87 - 11,37\% (Akbarillah et al., 2007). Menurut Trisyulianty et al. (2003), kadar air ditentukan oleh kadar air partikel sebelum kempa panas, kadar air yang terkandung dalam bahan perekat.

Kadar air yang dihasilkan dalam penelitian ini berkisar antara 6-8\%, hal ini menandakan bahwa biskuit yang dihasilkan terhindar dari serangan mikroorganisme yang dapat merusak biskuit dan memiliki daya simpan yang relatif lebih lama. Berdasarkan Standar SNI (1992), kadar air maksimal biskuit pakan ternak adalah 14\%, sedangkan Syarief (1986) dalam Trisyulianti et al. (2003) menyatakan bahwa aktivitas mikroorganisme dapat ditekan pada kadar air 12-14\%, sehingga bahan pakan tidak mudah berjamur dan membusuk. Rendahnya kadar air dari biskuit ransum komplit akan menghasilkan biskuit yang lebih awet dan dapat disimpan dalam waktu yang lebih lama.

\section{Kadar Protein Kasar Biskuit Ransum Komplit}

Protein kasar merupakan salah satu indikator dari banyak sedikitnya jumlah biskuit rumput lapang yang dimakan oleh ternak karena selain sebagai sumber protein juga dapat digunakan sebagai sumber energi (Retnani et al., 2009). Hasil analisis sidik ragam menunjukkan perlakuan berpengaruh nyata $(\mathrm{P}<0,05)$ terhadap kadar protein kasar biskuit ransum komplit. Hasil uji DMRT menunjukkan bahwa $\mathrm{P}_{5}$ berbeda nyata $(\mathrm{P}<0,05)$ terhadap perlakuan $\mathrm{P} 1$, namun keduanya tidak berbeda nyata terhadap perlakuan $\mathrm{P}_{2}, \mathrm{P}_{3}$ dan $\mathrm{P}_{4}$.

Kadar protein kasar biskuit ransum komplit dalam penelitian ini berkisar antara $10-12 \%$, dimana kadar protein kasar tertinggi terdapat pada perlakuan $\mathrm{P}_{5}$ ( $5 \%$ empulur sagu $+25 \%$ dedak padi), sedangkan yang terendah terdapat pada perlakuan P1 (25\% empulur sagu $+5 \%$ dedak padi). Tingginya kadar protein biskuit ransum komplit pada perlakuan $\mathrm{P}_{5}$ disebabkan karena persentase dedak padi yang digunakan lebih tinggi dibanding dengan perlakuan lainnya. Menurut Wibawa et al. (2015) bahwa kandungan protein kasar (PK) dedak padi adalah 10,93\% dari berat kering. Sedangkan menurut Akbarillah et al. (2007), kadar protein kasar dedak padi berkisar 9,02-12,41\%, lebih tinggi dibanding kadar protein kasar empulur sagu yang berkisar 0,25 - 0,48 \% (Purwani et al., 2006). Nilai gizi protein dedak relatif tinggi akibat kandungan lisinnya yang tinggi, dimana lisin merupakan salah satu asam amino esensial, dan dilaporkan juga bahwa nilai PER (protein efficiency ratio) dari dedak padi adalah 1,6-1,9 (Astawan dan Febrinda, 2010).

\section{Kadar Lemak Kasar Biskuit Ransum Komplit}

Kadar lemak dalam pakan selama penyimpanan erat kaitannya dengan timbulnya ketengikan dan meningkatnya serangan jasad renik yang disebabkan adanya keterkaitan antara tekanan uap, kelembaban dan kadar air. Pengemasan dan penyimpan yang baik akan mengurangi resiko pertumbuhan mikroorganisme sehingga perubahan kadar lemak kasar dapat diturunkan (Triyanto et al., 2013 ;). Hasil analisis sidik ragam menunjukkan bahwa pengunaan empulur sagu sebagai bahan perekat berpengaruh nyata $(\mathrm{P}<0,05)$ 
terhadap kadar lemak biskuit ransum komplit. Hasil uji DMRT menunjukkan bahwa perlakuan $\mathrm{P}_{5}$ berbeda nyata $(\mathrm{P}<0,05)$ terhadap perlakuan $\mathrm{P} 1$ dan $\mathrm{P} 2$, namun tidak berbeda nyata terhadap perlakuan $\mathrm{P}_{3}$ dan $\mathrm{P}_{4}$.

Hasil analisis proksimat menunjukkan persentasi kadar lemak tertinggi terdapat pada $\mathrm{P}_{5}$ ( $5 \%$ empulur sagu $+25 \%$ dedak padi) yaitu sebesar $3,35 \%$, sedangkan perlakuan P1 (25\% empulur sagu $+5 \%$ dedak padi) mempunyai kadar lemak terendah yaitu 1,72\%. Kadar lemak biskuit ransum komplit pada perlakuan $\mathrm{P}_{5}$ lebih tinggi disebabkan persentasi dedak padi yang lebih tinggi dan empulur sagu sebagai bahan perekat lebih sedikit. Kadar lemak kasar dedak padi berkisar 5,50 8,57\% (Akbarillah et al., 2007) lebih tinggi dibanding kadar lemak empulur sagu yang berkisar 0,03-0,12 \% (Purwani et al., 2006). Selain itu perbedaan kadar lemak ini kemungkinan disebabkan oleh perubahan kadar air bahan, suhu ruang penyimpanan dan kelembaban (Triyanto et al., 2013).

\section{Kadar Serat Kasar Biskuit Ransum Komplit}

Serat kasar sebagian besar berasal dari dinding sel tanaman yang mengandung selulosa, hemiselulosa dan lignin. Hasil penelitian menunjukkan kadar serat kasar biskuit ransum komplit berkisar antara 18,6220,87\%, dan hasil analisis sidik ragam menunjukkan bahwa penggunaan empulur sagu dan dedak padi tidak berpengaruh nyata $(\mathrm{P}>0,05)$ terhadap kadar serat kasar biskuit ransum komplit. Retnani et al. (2009) bahwa kadar serat kasar biskuit berkisar antara $27,25 \%$ - 42,49\% yang menggunakan rumput lapangan dan limbah tanaman jagung sebagai bahan dasarnya, maka hasil penelitian ini memiliki kadar serat kasar yang lebih rendah. Hal ini karena penggunaan empulur sagu dan dedak padi yang memikili kadar serat kasar yang lebih rendah dari limbah jagung. Perbedaan kadar serat kasar tersebut kemungkinan besar diakibatkan oleh semakin tebalnya dinding sel tanaman.

Serat kasar sangat berpengaruh terhadap kecernaan suatu bahan pakan, disamping itu juga berhubungan dengan daya serap air pada biskuit ransum komplit. Rendahnya kadar serat kasar cenderung menurunkan daya serap air. Tingginya kandungan serat menunjukkan bahwa biskuit mampu mengikat air karena adanya ikatan $\mathrm{OH}$ dalam air dengan serat pada biskuit. Penelitian Siregar (2005) dalam Riswandi et al. (2017) menyatakan bahwa terdapat hubungan positif antara daya serap air partikel dengan komposisi kimia fraksi serat bahan, sedangkan Haroen et al. (2007) dalam Riswandi et al. (2017), daya serap air oleh partisi yang terbuat dari limbah padat kaya serat memiliki kecenderungan semakin tinggi dengan meningkatnya persentase limbah padat yang ditambahkan.

\section{Kadar BETN Biskuit Ransum Komplit}

BETN merupakan bagian karbohidrat yang mudah dicerna. Komponen BETN terbesar adalah karbohidrat non struktural, seperti pati, monosakarida atau gula-gula. Hasil analisis sidik ragam menunjukkan bahwa penggunaan empulur sagu dan dedak padi berpengaruh nyata $(\mathrm{P}<0,05)$ terhadap kadar BETN biskuit ransum komplit. Hasil uji DMRT menunjukkan bahwa perlakuan P1 berbeda nyata terhadap perlakuan $\mathrm{P}_{2}, \mathrm{P}_{3}, \mathrm{P}_{4}$ dan $\mathrm{P}_{5}$, sedangkan $\mathrm{P}_{2}$ tidak berbeda nyata terhadap P4. Hasil analisis proksimat menunjukkan biskuit ransum komplit dengan kadar BETN tertinggi terdapat pada perlakuan P1 (25\% empulur sagu + $5 \%$ dedak padi), sedangkan kadar BETN terrendah terdapat pada perlakuan $\mathrm{P}_{5}$ (5\% empulur sagu $+25 \%$ dedak padi). Tingginya kandungan BETN pada perlakua P1 karena sumbangan empulur sagu yang digunakan dalam membuat biskuit ransum komplit memiliki kandungan BETN yang tinggi. Kandungan BETN semakin meningkat dengan semakin bertambahnya karbohidrat pada penggunaan empulur sagu. Dengan demikian dapat dikatakan bahwa dengan menggunakan empulur sagu dalam proses pembuatan biskuit ransum komplit dapat meningkatkan kadar BETN biskuit ransum komplit. Ampas sagu dapat menjadi alternatif bahan pakan sumber energi karena mengandung bahan ekstrak tanpa nitrogen (BETN) yang tinggi yaitu $76,51 \%$, tetapi ampas sagu kurang baik bila digunakan sebagai pakan tunggal karena berdasarkan bahan keringnya, ampas sagu memiliki kandungan protein kasar rendah (Sangadji, 2009).

\section{SIMPULAN}

Penggunaan empulur sagu sampai 25\% dan dedak padi 5\% (perlakuan P1) mempunyai kadar air tertinggi 7,14\%, protein kasar terrendah 10,19\%, lemak kasar terrendah 1,72\%, dan kadar BETN tertinggi 57,53\%. Sebaliknya penggunaan dedak padi yang lebih tinggi sampai 25\% dan empulur sagu 5\% (perlakuan $\mathrm{P}_{5}$ ) mempunyai kadar air terrendah 6,09\%, protein kasar tertinggi $11,99 \%$, dan lemak kasar tertinggi 3,35\%. Kualitas kimia biskuit pada perlakuan $\mathrm{P}_{5}$ lebih baik, karena kadar proteinnya lebih tinggi, tetapi kadar air dan kadar serat kasarnya lebih rendah.

\section{DAFTAR PUSTAKA}

Akbarillah, T., Hidayat, dan T. Khoiriyah. 2007. Kualitas dedak dari berbagai varietas padi di Bengkulu Utara. Jurnal Sain Peternakan Indonesia. 2(1): 36-41.

Astawan, M., dan A. E. Febrinda. 2010. Potensi dedak dan bekatul beras sebagai ingredient pangan 